DOI 10.26886/2520-7474.2(40)2020.1

UDC 378.14:378

\title{
RESEARCH ON THE USE OF DEVICE TYPES IN THE CYBERSECURITY TRAINING OF BACHELORS
}

\section{A. Samoylenko, PhD, Associate Professor}

\section{samoylenko aleksey@outlook.com}

Educational and Scientific Institute of Information Security of the Security Service of Ukraine, Kiev, Ukraine

\section{samoylenko aleksey@outlook.com}

The article presents the study of the use of device types in the process of training cybersecurity bachelors. The essence of the definition of cybersecurity has been clarified. The problems related to the preparation of bachelors in cybersecurity at the legislative level are characterized. The subject of the study was questions related to the types of devices used for learning on the Internet, among them: desktop computer, laptop, netbook, tablet, smartphone. The results of a three-semester study were released. A graphical comparative analysis of the dynamics of the study of the use of device types in the process of training cybersecurity bachelors is presented.

Keywords: cybersecurity, vocational training, cybersecurity bachelors, device.

У статті представлено дослідження стану використання типів девайсів в процесі профресійної підготовки бакалаврів 3 кібербезпеки. Уточнено сутність дефрініції «кібербезпека». Охарактеризовано проблеми, пов'язані із підготовкою бакалаврів 3 кібербезпеки на рівні законодавчої бази. Предметом дослідження стали питання, які стосуються типів девайсів, які використовуються для навчання в мережі Інтернет, серед них $\epsilon$ : стаціонарний комп'ютер, ноутбук, нетбук, планшет, смартфон. 
Оприлюднено результати дослідження, яке здійснювалось протягом трьох семестрів. Представлено графрічно порівняльний аналіз динаміки дослідження стану використання типів девайсів в процесі профресійної підготовки бакалаврів з кібербезпеки.

Ключові слова: кібербезпека, професійна підготовка, бакалаври з кібербезпеки, девайс.

Кандидат педагогических наук, доцент, Самойленко А. А., Исследование состояния использования типов девайсов в процессе профрессиональной подготовки бакалавров по кибербезопасности / Учебно-научный институт информационной безопасности Службы безопасности Украины, г. Киев, Украина.

В статье представлено исследование состояния использования типов девайсов в процессе профессиональной подготовки бакалавров по кибербезопасности. Уточнена сущность дефиниции «кибербезопасность». Охарактеризованы проблемы, связанные с подготовкой бакалавров по кибербезопасности на уровне законодательной базы. Предметом исследования стали вопросы, касающиеся типов комплектующих, которые используются для обучения в сети Интернет, в том числе являются: стационарный компьютер, ноутбук, нетбук, планшет, смартфон. Обнародованы результаты исследования, которое осуществлялось в течение трех семестров. Представлены графически сравнительный анализ динамики исследования состояния использования типов девайсов в процессе профрессиональной подготовки бакалавров по кибербезопасности.

Ключевые слова: кибербезопасность, профессиональная подготовка, бакалавры по кибербезопасности, девайс. 
Вступ. Підготовка бакалаврів до професійної діяльності у класичних університетах здійснюється чотири роки. В європейських країнах бакалаврат прийнято вважати першим ступенем загальної системи вищої освіти. По ходу навчання здобувач вищої освіти набуває базових практичних і теоретичних знань та компетентностей, що потрібні для роботи за фахом. Як визначається у Концепції педагогічної освіти України, бакалавр - це освітньо-кваліфікаційний рівень педагогічного працівника, який оволодів фундаментальними, соціально-гуманітарними, психолого-педагогічними і фраховими знаннями; має вміння та навички для здійснення навчально-виховного процесу в закладах освіти і здатний вирішувати типові професійні завдання, передбачені для посад учителів, вихователів, практичних психологів, соціальних педагогів і дефектологів у галузі освіти [1, р. 663].

В законі України про вищу освіту зазначено, що бакалавр - це освітній ступінь, що здобувається на першому рівні вищої освіти та присуджується вищим навчальним закладом у результаті успішного виконання здобувачем вищої освіти освітньо-професійної програми, обсяг якої становить 180-240 кредитів ЄКТС. Обсяг освітньопрофесійної програми для здобуття ступеня бакалавра на основі ступеня молодшого бакалавра визначається вищим навчальним закладом. [2]

Мета: Дослідження стану використання типів девайсів в процесі професійної підготовки бакалаврів з кібербезпеки

\section{Виклад основного матеріалу.}

Кібербезпека - це захищеність від наявних та потенційно небезпечних проявів інформаційних загроз для нормального функціонування інформаційних систем, а також комплекс заходів та засобів, що спрямовані на захист комп'ютерів, обчислювальних мереж 
від несанкціонованого доступу та інших дій, пов'язаних з крадіжкою, блокуванням, пошкодженням, руйнуванням та знищенням як випадкового, так і цілеспрямованого впливу [3, 4].

В Законі України про основні засади забезпечення кібербезпеки України надається таке визначення кібербезпеки: це захищеність життєво важливих інтересів людини і громадянина, суспільства та держави під час використання кіберпростору, за якої забезпечуються сталий розвиток інформаційного суспільства та цифрового комунікативного середовища, своєчасне виявлення, запобігання і нейтралізація реальних і потенційних загроз національній безпеці України у кіберпросторі [5].

Як зазначають професійна підготовка фахівців потребує переосмислення мети, завдань, змісту і методів педагогічного процесу відповідно за сучасними проблемами та перспективами суспільного розвитку. Автори відзначають, що одержання закладами вищої освіти автономності, зумовлює потребу розроблення сучасних стандартів, які б відображали основні вимоги до сукупності якостей випускника, а також засобів їх досягнення. [6, pp. 22-23].

Ми будемо розуміти під підготовкою бакалавра з кібербезпеки процес формування готовності до діяльності, що пов'язана 3 оволодінням, визначеним професією за напрямком та метою захищеності життєво важливих інтересів людини і громадянина, суспільства та держави під час використання кіберпростору, за якої забезпечуються сталий розвиток інфрормаційного суспільства та цифрового комунікативного середовища, своєчасне виявлення, запобігання і нейтралізація реальних і потенційних загроз національній безпеці України у кіберпросторі 
Тенденція розвитку підготовки бакалаврів з кібербезпеки вимагає обміну досвідом на світовому рівні, а отже виникає потреба у дослідженні стану використання типів девайсів в процесі професійної підготовки.

3 метою дослідження стану використання типів девайсів в процесі професійної підготовки бакалаврів з кібербезпеки нами було проведено анкетування протягом трьох навчальних семестрів. В анкетуванні брали участь здобувачі вищої освіти спеціальності 125 «Кібербезпека» у кількості 187 осіб і викладачі, які викладають навчальні дисципліни для здобувачів вищої освіти спеціальності «Кібербезпека», а також ті, які мають досвід використання технологій мережевого навчання у кількості 68 осіб. До експериментального опитування були залучені представники таких закладів вищої освіти, як Міжрегіональна академія управління персоналом, Комунальний вищий навчальний заклад «Херсонська академія неперервної освіти» та Національний педагогічний університет імені М.П. Драгоманова.

Предметом дослідження стали питання, які стосуються типів девайсів, які використовуються для навчання в мережі Інтернет. Серед них $€$ наступні: стаціонарний комп'ютер, ноутбук, нетбук, планшет, смартфон. Результати опитування представлені нижче (Таблиця 1).

Таблиця 1.

Дослідження стану використання типів девайсів в процесі професійної підготовки бакалаврів з кібербезпеки

\begin{tabular}{|c|c|c|}
\hline Типи девайсів, які & здобувачами вищої & викладачами у \\
використовуються в & освіти у & відсотковому \\
процесі професійної & відсотковому & співвідношенні \\
підготовки 3 & співвідношенні & \\
\hline
\end{tabular}




\begin{tabular}{|c|c|c|c|c|c|c|}
\hline кібербезпеки & 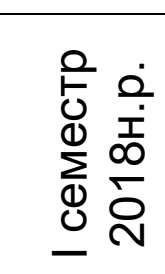 & 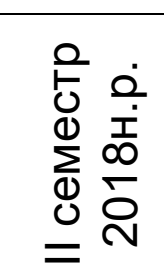 & 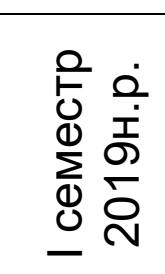 & 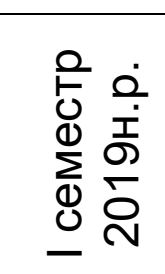 & 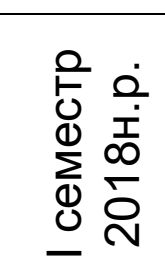 & 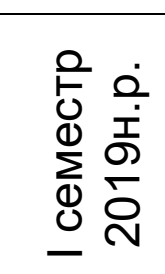 \\
\hline $\begin{array}{l}\text { Стаціонарний } \\
\text { комп'ютер }\end{array}$ & $47,3 \%$ & $31,2 \%$ & $18,9 \%$ & $65,3 \%$ & $55,8 \%$ & $51,7 \%$ \\
\hline Ноутбук & $49,3 \%$ & $45,8 \%$ & $73,2 \%$ & $40,4 \%$ & $40,9 \%$ & $49,2 \%$ \\
\hline Нетбук & $22,3 \%$ & $32,9 \%$ & $33,8 \%$ & $13,3 \%$ & $19,2 \%$ & $19,9 \%$ \\
\hline Планшет & $75,3 \%$ & $81,4 \%$ & $95,5 \%$ & $12,5 \%$ & $30,2 \%$ & $44,8 \%$ \\
\hline Смартфон & $93,5 \%$ & $96,3 \%$ & $98,5 \%$ & $31,9 \%$ & $39,3 \%$ & $44,2 \%$ \\
\hline
\end{tabular}

В результаті дослідження можна простежити регрес у використанні стаціонарних комп'ютерів як у бакалаврів з кібербезпеки, так і у викладачів, які їх навчають. Цей факт можна пояснити тим, що в сучасному світі домінує мобільність, а кожна людина, цінуючи власний час, обирає такий девайс, який здатен забезпечити ії.

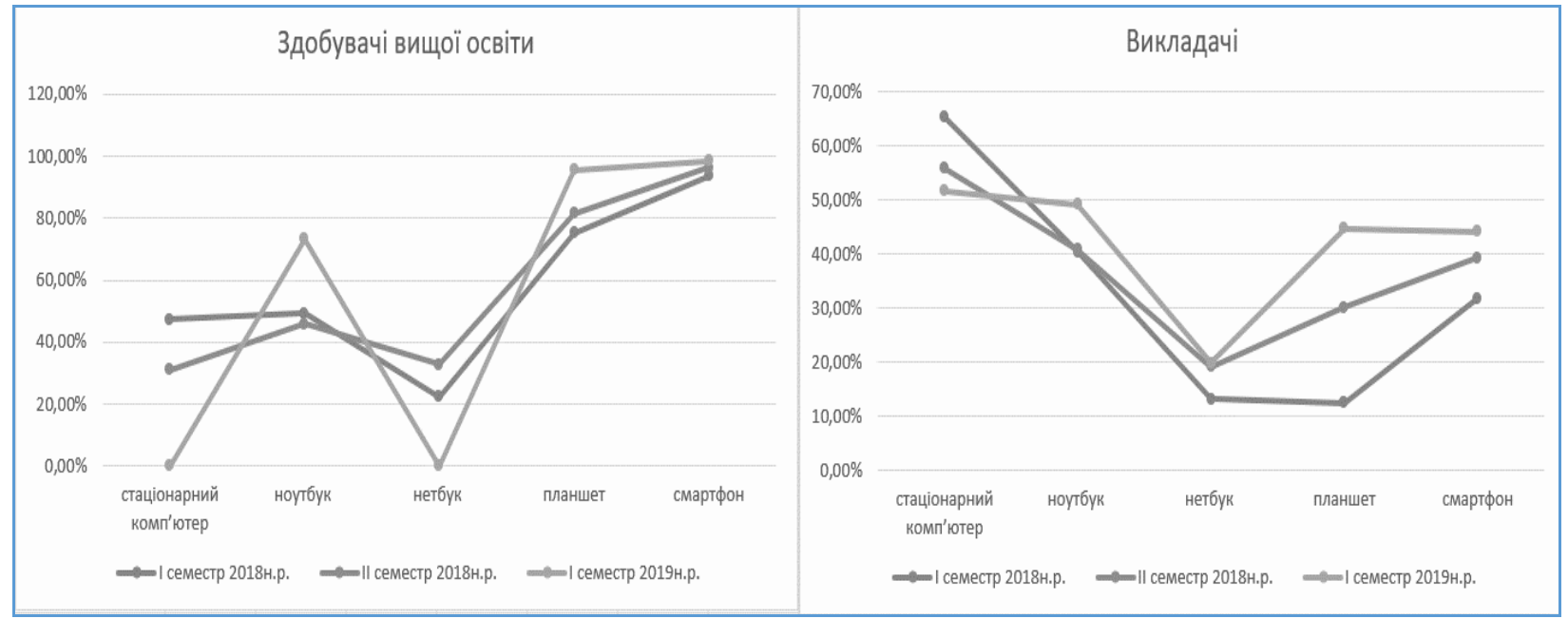

Рис. 1. Динаміка дослідження стану використання типів девайсів в процесі професійної підготовки бакалаврів з кібербезпеки

Прогрес спостерігається серед стану використання ноутбуків та менше нетбуків. Протягом дослідження показник прогресу серед бакалаврів з кібербезпеки складає майже 20\%, серед викладачів майже 10\%. Стан використання нетбуків збільшився на 11\% серед майбутніх бакалаврів з кібербезпеки. 
Висновки. Найвищі показники зафіксовані стосовно використання планшета та смартфона. Серед здобувачів вищої освіти 125-ї спеціальності приріст складає відповідно 20\% та 7\%, у викладачів - 32\% та 13\%. Також зазначимо, що прогрес наближається до 100\% значення серед здобувачів вищої освіти, а у викладачів наближається до $50 \%$. Це можна пояснити з позицій вікового співвідношення. Відповідно викладачам потрібна допомога в удосконаленні знань щодо використання сучасних планшетних та мобільних пристроїв в освітньому процесі. Здобувачам вищої освіти відповідно потрібен освітній контент, доступ до якого може бути спрощеним за рахунок мобільних та планшетних пристроїв.

\section{תimepamypa:}

1. Артюх, С. Ф., Ашеров, А. Т., \& Лобунец, В. И. (1998). Концепция инженерно-педагогического образования в Украине. Регіональні перспективи (наук.-прак. журнал)(№ 2 (3)), С. 21-25.

2. Законодавство України. (2014). Закон України про вищу освіту. Отримано 08082019 р. 3 https://zakon.rada.gov.ua/laws/show/298414/ed20020117/find?text=\%CF\%F0\%EE\%F4\%E5\%F1\%B3\%E9\%ED\%E0+ \%EF\%B3\%E4\%E3\%EE\%F2\%EE\%E2\%EA\%E0

3. Законодавство України. (2018). Закон України про основні засади забезпечення кібербезпеки України. Отримано 13. 01.2020 р. 3 https://zakon.rada.gov.ua/laws/show/2163-19

4. Кафредра інженерії програмного забезпечення та кібербезпеки. (2019). Спеціальність "Кібербезпека" ОС "бакалавр". Київ. Отримано 13. 01.2020 p. 3 https://knute.edu.ua/blog/read/?pid=26063\&uk

5. Любар, О. О. (2005). Історія української школи і педагогіки: Хрестоматія. Концепція педагогічної освіти (23.12.1998), 658 - 670. (К. В. Г., Ред.) Київ: Знання. 
6. Освітня програма зі спеціальності 125 «Кібербезпека». (2019). Отримано 14. 01.2020 p. 3 http://vstup.knuba.edu.ua/ukr/wpcontent/uploads/2019/02/125_\%D0\%91/\%D0\%9A\%D0\%A1_\%D0\%9C\%D0 $\% 90 \%$ D0\%93.pdf

\section{References:}

1. Zakonodavstvo Ukrainy. (2014). Zakon Ukrainy pro vyshchu osvitu. Otrymano 08082019 p. z https://zakon.rada.gov.ua/laws/show/298414/ed20020117/find?text=\%CF\%F0\%EE\%F4\%E5\%F1\%B3\%E9\%ED\%E0+ \%EF\%B3\%E4\%E3\%EE\%F2\%EE\%E2\%EA\%E0

2. Zakonodavstvo Ukrainy. (2018). Zakon Ukrainy pro osnovni zasady zabezpechennia kiberbezpeky Ukrainy. Otrymano 13. 01.2020 p. z https://zakon.rada.gov.ua/laws/show/2163-19

3. Kafedra inzhenerii prohramnoho zabezpechennia ta kiberbezpeky. (2019). Spetsialnist "Kiberbezpeka" OS "bakalavr". Kyiv. Otrymano 13. 01. 2020 p. z https://knute.edu.ua/blog/read/?pid=26063\&uk

4. Liubar, O. O. (2005). Istoriia ukrainskoi shkoly i pedahohiky: Khrestomatiia. Kontseptsiia pedahohichnoi osvity (23.12.1998), 658 - 670. (K. V. H., Red.) Kyiv: Znannia.

5. Osvitnia prohrama zi spetsialnosti 125 «Kiberbezpeka». (2019). Otrymano 14. 01.2020 p. $\quad$ z $\quad$ http://vstup.knuba.edu.ua/ukr/wpcontent/uploads/2019/02/125_\%D0\%91/\%D0\%9A\%D0\%A1_\%D0\%9C\%D0 $\% 90 \%$ D0\%93.pdf 